\title{
Displacive Transformations and their Applications in Structural Ceramics
}

\author{
W.M. Kriven \\ Department of Materials Science and Engineering, University of Illinois at Urbana-Champaign, 105 South \\ Goodwin Avenue, Urbana, IL 61801 U.S.A.
}

\begin{abstract}
The current status of knowledge of first order, potentially displacive transformations in ceramics is reviewed. Those proven to be martensitic in bulk, single phase materials are the tetragonal to monoclinic transformation in zirconia $\left(\mathrm{ZrO}_{2}\right)$ and the cubic to tetragonal symmetry change in lead titanate $\left(\mathrm{PbTiO}_{3}\right)$. Numerous transformations in a variety of other ceramic materials have been reported and the incompleteness of the data is here indicated. The relevance of displacive and martensitic transformations to toughening mechanisms for reducing brittleness has been demonstrated. The mechanisms are: (i) transformation toughening of composites; (ii) transformation weakening of critical interphases in composites; and (iii) mechanical rearrangement of domains arising from ferroelastic transformations in monoliths. Another potential application lies in their use as large force actuators in adaptive (smart) systems. Transformations mechanisms need to be elucidated in the context of the sequential loss or gain of symmetry on cooling or heating. The coupling of mechanical forces to induce nucleation, as well as their interaction with the crystallographic volume and shape changes accompanying transformation, need to be understood and controlled. This fundamental knowledge will guide the microstructural tailoring of monoliths and composites to achieve useful coupling, and thus enhanced mechanical properties.
\end{abstract}

\section{INTRODUCTION}

Apart from ferroelectric transformations in electronic ceramics [1], and amorphous to crystalline phase equilibria changes in glass, first order phase transformations in ceramics have traditionally received little attention [2]. However, the deleterious effects of transformations in zirconia $\left(\mathrm{ZrO}_{2}\right)$ or silica $\left(\left(\mathrm{SiO}_{2}\right)\right.$, as cristobalite or quartz) are widely known in the refractories industry. More recently since 1975 [3] however, the demonstration of enhanced thermal shock resistance in composites containing zirconia has reversed the negative connotations associated with phase transformations in structural ceramics. It was demonstrated that if properly controlled, the martensitic tetragonal to monoclinic transformation in zirconia could produce quite beneficial mechanical properties, in particular, in toughness or reduced brittleness, in zirconia-containing composites. During the past fifteen years, several attempts surveys have been made in the field of phase transformations in ceramics, searching from an interdisciplinary perspective in the areas of ceramics, minerals, cementitious and other inorganic compounds [4-9]. The aim of this review is to continue stock taking of currently known transformations in ceramics, but also to indicate recent potential applications of ceramic transformations in structural ceramic composites and monoliths.

\section{SOME KNOWN PHASE TRANSFORMATIONS IN CERAMICS}

Table 1 [9] is a brief summary of some phase transformations in ceramics which are thought to be displacive. This is only a partial list however, since for each compound, only the phase transformation of most interest is listed, and in fact each compound may undergo several transformations. Thus a deeper and more accurate understanding of a particular transformation may be gained within the context of transformations preceding or following it. For example, from a comprehensive study of the four sequential transformations in dicalcium silicate $\left(\mathrm{Ca}_{2} \mathrm{SiO}_{4}\right)$, the $\beta$ to metastable $\gamma$ transformation, which is accompanied by an $\sim 12 \%$ volume increase, was identified as part of a ferroelastic series [10]. 
Table 1. Examples of First Order Displacive Transformations in Ceramics

\begin{tabular}{|c|c|c|c|c|}
\hline Compound & $\begin{array}{l}\text { Crystal } \\
\text { Symmetries }\end{array}$ & $\begin{array}{l}\text { Transformation } \\
\text { Temperature } \\
\text { (To.en cooling) }\end{array}$ & $\begin{array}{c}\text { Volume } \\
\text { Change }(\Delta V)\end{array}$ & $\begin{array}{l}\text { Unit Ceil } \\
\left.\text { Shape Change }{ }^{\circ}\right)\end{array}$ \\
\hline $\begin{array}{l}\mathrm{ZrO}_{2} \\
\text { (also } \mathrm{HfO}_{2} \text { ) }\end{array}$ & $\begin{array}{l}\text { tetragonal } \rightarrow \\
\text { monoclinic }\end{array}$ & 950 & $\begin{array}{c}(+) 4.9 \% \\
\text { (R.T.) }\end{array}$ & 9 \\
\hline $\begin{array}{l}\mathrm{Ln}_{2} \mathrm{O}_{3} \\
\text { (type) }\end{array}$ & $\begin{array}{l}\text { monoclinic } \rightarrow \\
\text { cubic }\end{array}$ & $600-2200$ & $(+) 10 \%$ & 10 \\
\hline $\begin{array}{l}\mathrm{Ca}_{2} \mathrm{SiO}_{4} \\
\text { (K2 } \mathrm{SO}_{4} \text {-type) }\end{array}$ & $\begin{array}{l}\text { monoclinic } \rightarrow \\
\text { orthorhombic }\end{array}$ & 490 & $(+) 12 \%$ & 4.6 \\
\hline $\begin{array}{l}\mathrm{Sr}_{2} \mathrm{SiO}_{4} \\
\left(\mathrm{~K}_{2} \mathrm{SO}_{4} \text {-type }\right)\end{array}$ & $\begin{array}{l}\text { orthorhombic } \rightarrow \\
\text { monoclinic }\end{array}$ & 90 & $0.2 \%$ & 2 \\
\hline $\mathrm{NiS}$ & $\begin{array}{l}\text { rhombohedral } \rightarrow \\
\text { hexagonal }\end{array}$ & 379 & $(+) 4 \%$ & - \\
\hline $\begin{array}{l}2 \mathrm{~Tb}_{2} \mathrm{O}_{3} \cdot \mathrm{Al}_{2} \mathrm{O}_{3} \\
\text { (type) }\end{array}$ & $\begin{array}{l}\text { orthorhombic } \rightarrow \\
\text { monoclinic }\end{array}$ & 1070 & $(+) 0.67 \%$ & 18.83 \\
\hline $\mathrm{PbTiO}_{3}$ & $\begin{array}{l}\text { cubic } \rightarrow \\
\text { tetragonal }\end{array}$ & 445 & $(+) 1 \%$ & 0 \\
\hline $\mathrm{KNbO}_{3}$ & $\begin{array}{l}\text { tetragonal } \rightarrow \\
\text { orthorhombic }\end{array}$ & 225 & $\sim 0 \%$ & 0 \\
\hline $\mathrm{LuBO}_{3}$ & $\begin{array}{l}\text { hexagonal } \rightarrow \\
\text { rhombohedral }\end{array}$ & 1310 & $(+) 8 \%$ & - \\
\hline $\begin{array}{l}\mathrm{MgSiO}_{3} \\
\text { (CaSiO} 3 \text {-type) } \\
\text { (FeSiO } 3 \text {-type) }\end{array}$ & $\begin{array}{l}\text { orthorhombic } \rightarrow \\
\text { monoclinic }\end{array}$ & 865 & $(-) 5.5 \%$ & 18.3 \\
\hline $\begin{array}{l}\mathrm{YNbO}_{4} \\
\left(\mathrm{LnNbO}_{4} \text {-type }\right)\end{array}$ & $\begin{array}{l}\text { tetragonal } \rightarrow \\
\text { monoclinic }\end{array}$ & 900 & (-) $1.8 \%$ & 4.53 \\
\hline $\mathrm{LnBO}_{3}$ (type) & $\begin{array}{l}\text { hexagonal } \rightarrow \\
\text { hexagonal }\end{array}$ & $550-800$ & $(-) 8.2 \%$ & - \\
\hline
\end{tabular}

In addition to those compounds listed in Table 1, other reports of transformations in ceramics include [9]: a tetragonal to monoclinic-like transformation in zircon $\left(\mathrm{ZrSiO}_{4}\right)$ on heating at $827^{\circ} \mathrm{C}$ [11]; a $\beta \rightarrow \gamma$ transformation in $\mathrm{Li}_{3} \mathrm{PO}_{4}$ at $-340^{\circ} \mathrm{C}$ [12]; a monoclinic to rhombohedral transformation in the $\mathrm{NaSiCON}$-type $\mathrm{LiSn}_{2}\left(\mathrm{PO}_{4}\right)_{4}[13]$; as well as transformations in aluminum titanate $\left(\mathrm{Al}_{2} \mathrm{TiO}_{5}\right)$, barium ortho-titanate $\left(2 \mathrm{BaO} \cdot \mathrm{TiO}_{2}\right.$ or $\left.\mathrm{Ba}_{2} \mathrm{TiO}_{4}\right)$ and cerium pyrosilicate $\left(\mathrm{CeSiO}_{4}\right)$.

Recent work has been underway by C. M. Wayman, D. A. Payne H. Chen and colleagues at the University of Illinois at Urbana-Champaign on phase transformations in lead titanate ( $\left.\mathrm{PbTiO}_{3}\right)_{\text {[14-19] }}$ and the rare earth niobates $\left(\mathrm{LaNbO}_{4}\right)$ [20-25]. Other phase transformations identified include a hexagonal to orthorhombic transformation in the lanthanide titanates $\left(\mathrm{Ln}_{2} \mathrm{TiO}_{5}\right)$ above $1500^{\circ} \mathrm{C}$, but little is known about the mechanism. 
The displacive $\beta$ to $\alpha$ transformation in cristobalite $\left(\mathrm{SiO}_{2}\right)$ at $265^{\circ} \mathrm{C}[26,27]$ is well known in the context of the transformations among its other metastable and stable phases. Aluminum phosphate $\left(\mathrm{AIPO}_{4}\right)$ is isostructural with cristobalite [28].

There are four known polymorphs of $\mathrm{BaAl}_{2} \mathrm{Si}_{2} \mathrm{O}_{8}$. Celsian and paracelsian are naturally occurring minerals having framework aluminosilicate structures [30]. Hexacelsian is the stable high temperature phase of $\mathrm{BaAl}_{2} \mathrm{Si}_{2} \mathrm{O}_{8}$ existing under equilibrium conditions between $1590^{\circ} \mathrm{C}$ and the melting point of $1760^{\circ} \mathrm{C}[31,32]$, while below $1590^{\circ} \mathrm{C}$ celsian is the stable phase (Figure 1). Hexacelsian is structurally quite different from celsian and is composed of double layer sheets of $(\mathrm{Al}, \mathrm{Si}) \mathrm{O}_{4}$ tetrahedra with the barium cations located between the layers. Due to the reconstructive nature of the hexacelsian to celsian transformation, hexacelsian is easily retained as a metastable phase to room temperature. A displacive $\beta$ to $\alpha$ transformation takes place at $\sim 300^{\circ} \mathrm{C}$ in hexacelcian [29-39] which is based on the Ba-feldspar structure. The transformation has a volume contraction on cooling of $\sim 0.6 \%$. In the strontium based feldspar this temperature is raised to $\sim 760^{\circ} \mathrm{C}[39]$.

Leucite $\left(\mathrm{KAlSi}_{2} \mathrm{O}_{6}\right)$ is a framework aluminosilicate which undergoes two apparently ferroelastic transformations on cooling to RT (Figure 2) [40-45]. The volume change associated with both transformations is $(-)-3.5 \%$ at RT including the thermal expansion coefficients. Leucite would not normally be considered as a potential component for high temperature structural ceramics due to its large coefficeint of thermal expansion. The large CTE, however, is confined to the low temperature tetragonal phase. High temperature measurements indicate that the CTE of the cubic phase is significantly lower, at $\sim 7 \mathrm{x}^{10-6 / \mathrm{C}}[44]$.

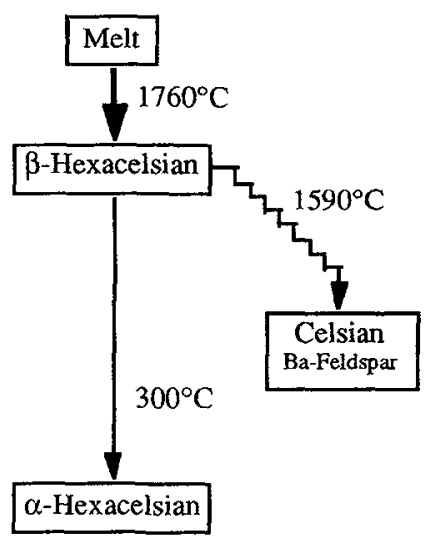

Figure 1: Polymorphs of celsian $\left(\mathrm{BaAl}_{2} \mathrm{Si}_{2} \mathrm{O}_{8}\right)$

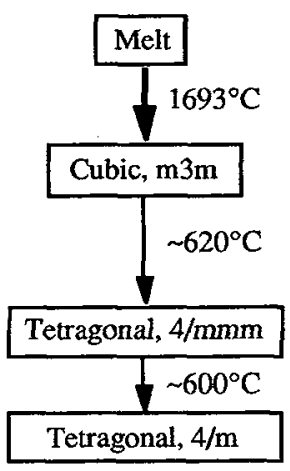

Figure 2: Polymorphs of leucite $\left(\mathrm{KAlSi}_{2} \mathrm{O}_{6}\right)$

The existence of di-lanthanide aluminates was discovered through phase equilibria studies [46] which also detected a displacive phase transformation above $1000^{\circ} \mathrm{C}$ for the yttrium compound, $\mathrm{Y}_{4} \mathrm{Al}_{2} \mathrm{O}_{9}$ [47]. In addition to the high transformation temperature, one of the most appealing aspects of these materials is the possibility for use with yttrium aluminum garnet $\left(\mathrm{Y}_{3} \mathrm{Al}_{5} \mathrm{O}_{12}\right.$ or YAG). YAG is one of the more desirable ceramics for high temperature applications due to its excellent mechanical properties at high temperature including creep resistance.

Phase equilibria studies which have been performed on the $\mathrm{Y}_{2} \mathrm{O}_{3}-\mathrm{Al}_{2} \mathrm{O}_{3}$ system [47-50] are not in agreement on the stability of the 1:1 perovskite compound $\mathrm{YAlO}_{3}$. Noguchi and Mizuno [48] report that $\mathrm{YAlO}_{3}$ is stable only above $1800^{\circ} \mathrm{C}$. However, it is easily retained to room temperature as a metastable phase. The $\mathrm{R}_{4} \mathrm{Al}_{2} \mathrm{O}_{9}$ compounds are structurally "pyro"-aluminates possessing two $\mathrm{AlO}_{4}$ tetrahedra connected by the sharing of an oxygen corner. The rare earth cations form two 6-coordinated and two 7coordinated polyhedra with oxygen [51,52]. High temperature phase transformations have been reported for the $\mathrm{Y}_{4} \mathrm{Al}_{2} \mathrm{O}_{9}$ [53] and $\mathrm{Tb}_{4} \mathrm{Al}_{2} \mathrm{O}_{9}$ [54] compounds. Transformation temperatures on cooling were reported as $1338^{\circ} \mathrm{C}$ and $1070^{\circ} \mathrm{C}$ respectively with significant thermal hystereses. The volume change was small and positive on cooling. The high temperature crystal structure for these compounds is not known, although it is likely to be orthorhombic, based on the relatively small deviation from orthorhombic symmetry in the low temperature phase, and based on the (201) twinning which has been observed in the 
closely related disilicate minerals [55-57]. The $\sim 1400^{\circ} \mathrm{C}$ transformation temperature of $\mathrm{Y}_{4} \mathrm{Al}_{2} \mathrm{O}_{9}$ may present some difficulties. Based on cation size principles [58], however, the Dy and Gd compounds should have slightly lower transformation temperatures and may be more suitable for some experiments.

Table 2 lists some known other types of phase transformations and information sought about them. It is apparent that numerous phase transformations can be found in ceramics, but that little is systematically and comprehensively known about them. Furthermore, our knowledge to date suggests that those reported are each in themselved a part of a series of changes form one crystal structure to another, within the same compound. Note for example the ferroelastic sequence between the five polymorphic transformations in dicalcium silicate $\left(\mathrm{Ca}_{2} \mathrm{SiO}_{4}\right)$. In general, the tendency is for high symmetry structures to sequentially revert to lower symmetry structures with decreasing temperatures.

Table 2. Other Examples of Phase Transformations in Ceramics

\begin{tabular}{|c|c|c|c|c|}
\hline Compound & $\begin{array}{c}\text { Crystal } \\
\text { Symmetries }\end{array}$ & $\begin{array}{l}\text { Transformation } \\
\text { Temperature } \\
\text { (Toon cooling) }\end{array}$ & $\begin{array}{c}\text { Yolume } \\
\text { Change } \\
(\Delta V)\end{array}$ & $\begin{array}{l}\text { Unit Cell } \\
\text { Shape } \\
\left.\text { Change( }{ }^{\circ}\right)\end{array}$ \\
\hline $\begin{array}{l}\text { Cristobalite } \\
\left(\mathrm{SiO}_{2}\right)\end{array}$ & $\begin{array}{l}\text { cubic } \rightarrow \\
\text { tetragonal }\end{array}$ & 265 & (-) $2.8 \%$ & 0 \\
\hline $\begin{array}{l}\text { Hexacelcian } \\
\left(\mathrm{BaAl}_{2} \mathrm{Si}_{2} \mathrm{O}_{8}\right)\end{array}$ & hexagonal $\rightarrow$ & 300 & (-) $0.43 \%$ & 0 \\
\hline $\begin{array}{l}\text { Leucite } \\
\text { (KAlSi2 } \mathrm{O}_{6} \text { ) }\end{array}$ & $\begin{array}{l}\text { cubic } \rightarrow \\
\text { tetragonal }\end{array}$ & 620 & $\sim 0$ & 0 \\
\hline Zircon $\left(\mathrm{ZrSiO}_{4}\right)$ & $\begin{array}{l}\text { monoclinic } \rightarrow \\
\text { tetragonal }\end{array}$ & 827 & $?$ & $?$ \\
\hline $\begin{array}{l}\text { Di-lanthanide } \\
\text { aluminates } \\
\left(\mathrm{Ln}_{4} \mathrm{Al}_{2} \mathrm{O}_{9}\right)\end{array}$ & $\begin{array}{l}\text { monoclinic } \rightarrow \\
\text { monoclinic }\end{array}$ & 1400 & (+) $0.05 \%$ & $?$ \\
\hline $\begin{array}{l}\text { Di-lanthanide } \\
\text { titantes }\left(\mathrm{Ln}_{2} \mathrm{TiO}_{5}\right)\end{array}$ & $\begin{array}{l}\text { hexagonal } \overrightarrow{ } \\
\text { orthorhombic }\end{array}$ & 1712 & $?$ & 0 \\
\hline $\begin{array}{l}\text { Barium } \\
\text { orthotitanate } \\
\left(\mathrm{Ba}_{2} \mathrm{TiO}_{4}\right)\end{array}$ & 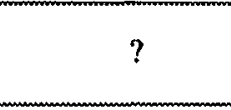 & $?$ & $?$ & $?$ \\
\hline $\begin{array}{l}\text { Cerium } \\
\text { pyrosilicate } \\
\left(\mathrm{CeSiO}_{4}\right)\end{array}$ & $?$ & $?$ & $?$ & $?$ \\
\hline $\begin{array}{l}\text { Aluminum titanate } \\
\left(\mathrm{Al}_{2} \mathrm{TiO}_{5}\right)\end{array}$ & ? & ? & ? & ? \\
\hline $\begin{array}{l}\text { Lithium phosphate } \\
\left(\mathrm{Li}_{2} \mathrm{PO}_{4}\right)\end{array}$ & $?$ & 340 & $?$ & $?$ \\
\hline $\begin{array}{l}\text { Lanthanide (eg.Gd) } \\
\text { vanadates }(\mathrm{LnVO})\end{array}$ & $\begin{array}{l}\text { monoclinic } \rightarrow \\
\text { tetragonal }\end{array}$ & 825 & $?$ & $?$ \\
\hline
\end{tabular}

\section{APPLICATIONS IN STRUCTURAL CERAMICS}

\subsection{Transformation toughening of composites}

It is now well established that the tetragonal $(t)$ to monoclinic $(m)$ transformation in zirconia $\left(\mathrm{ZrO}_{2}\right)$ is able to enhance the toughness of a ceramic matrix by three to four-fold [59-64]. The toughening effect is attributed to the interaction of a stress field at a propagating crack tip, with metastable retained tetragonal $\mathrm{ZrO}_{2}$ particles. The microstructures of partially stabilized zirconia's (e.g., Mg-PSZ or 3Y-TZP) or of zirconia toughened alumina (ZTA) have been tailored such that the $\mathrm{ZrO}_{2}$ particles are held metastable by the following parameters [65]:

(i) a confining matrix constraint

(ii) chemical composition or doping effects

(iii) a critical particle size effect controlling the onset of nucleation of the transformation. 
The $t \rightarrow m$ transformation is considered to be martensitic in the bulk [66-68] and accompanied by a $3.04 \%$ volume increase at the $\mathrm{M}_{\mathrm{S}}$ temperature of $950^{\circ} \mathrm{C}$ or $4.9 \%$ at room temperature, taking into consideration the thermal contraction effects [69]. The mechanism of transformation toughening is attributed to energy dissipation of the propagating crack by nucleation of the $\mathbf{t} \rightarrow \mathbf{m}$ transformation in its crack tip stress field, followed by the exertion of closure forces on the crack resulting from the volume expansion experienced by transformed $\mathrm{ZrO}_{2}$ particles lying in the transformation zone of the crack.

Modeling of the mechanical interactions during transformation toughening recognized the two roles of dilation and shape change accompanying the transformation [70-72]. However, the models developed to date have only been compared with experimental observations in zirconia systems. Therefore, based on crystallographic considerations of volume versus shape changes, other ceramics or minerals were identified as possible alternative transformation toughness, having various combinations of volume increase and/or unit cell shape changes [7,8]. Among these, the lanthanide sesquioxides were identified as candidate high temperature transformation tougheners $[7,8]$. They experience an 8 to $10 \%$ volume increase and unit cell shape change of $10^{\circ}$ on transformation from high temperature cubic (c) to low temperature monoclinic (m) symmetry, when the transformation was extrapolated to room temperature lattice parameters [7]. Consideration of lattice parameters for dysprosia $\left(\mathrm{Dy}_{2} \mathrm{O}_{3}\right)$ at the transformation temperature $\left(\mathrm{T}_{0}\right)$ of $1850^{\circ} \mathrm{C}$ on cooling indicated a volume increase of 5.07\% [73]. A composite of $20 \mathrm{vol} \%$ of terbia $\left(\mathrm{Tb}_{2} \mathrm{O}_{3}\right)$ of $\mathrm{T}_{\mathrm{o}} 1590^{\circ} \mathrm{C}$, dispersed in a matrix of magnesia $(\mathrm{MgO})$ yielded a three-fold increase in toughness at a temperature of $1400^{\circ} \mathrm{C}[74,75]$. Further work needs to be done to explore the high temperature stability of this system. However, kinetic and crystallographic studies $[73,76-78]$ indicate that the cubic to monoclinic transformation in the lanthanide sesquioxide may be displacive.

\subsection{Transformation Weakening of Ceramic Interphases}

\subsubsection{Concept}

Most of the advanced materials are composites having various types of reinforcing elements such as fibers, whiskers, particulates, etc., embedded in a matrix material. Unavoidably, these constitute large amounts of interfacial surface inside the composite. The deflection of a crack along such an interface or the separation of the interface due to the action of an impinging crack is an important mechanism for enhancing the fracture toughness of these composites. In a fiber-reinforced composite, for example, the advancing crack can debond along the interface and inhibit fiber failure, or it can directly advance through the fiber. If debonding occurs, then the intact fibers will allow crack bridging and eventual fiber pullout, thus giving rise to increased toughness of the composite. The previous studies on fiberreinforced composites have shown that the extensive fiber pullout can be induced by formation of a weak interface layer between the fiber and matrix. This has led to investigations of composites with coated fibers. The most common choices of coatings, for example in SiC/SiC composite, are carbon and boron nitride. Both carbon and boron nitride surfaces on $\mathrm{SiC}$ fibers have been shown to weaken the bonding of the fiber/matrix interface and to enhance fiber pullout at room temperature and at somewhat elevated temperatures. However, either coating is probably not appropriate for extended use ( $\geq 10$ hours) in an oxidizing environment at elevated temperatures $\left(T \geq 1200^{\circ} \mathrm{C}\right)$. The same can be also expected for most other nitride- and carbide-coating compositions. Therefore, the search for a new type of fiber-matrix interface becomes a key factor in developing brittle-matrix composites for high and even intermediate temperature applications.

The concept of "phase transformation weakening" introduced here has led to the search for a displacive or martensitic phase transformation with a negative volume change or large shape change at fiber/matrix or laminate/matrix interfaces. In applying such a phase transformation, a distinction is drawn between a thermally induced transformation and a shear stress induced transformation. Fig. 3 illustrates a mechanism for shear stress induced weakening of an interface and thereby, overall toughening of a composite. The difference between a shear induced mechanism and a thermally induced one is that in the latter, all the interfacial grains have already been transformed prior to crack approach.

The main features and potential advantages of transformation weakened interfaces can be summarized as:

(1) An oxide coating at the interfaces between oxide fibers embedded in an oxide matrix or in a laminated composite will allow chemical stability in a oxidizing environment.

(2) Strong bonding, and hence good overall strength of the composite, can be switched to weak bonding in the localized region of an incoming crack when the shear stresses associated with the crack-fiber or laminate interface induce a transformation in the coating. Thus the interface strength can be varied as it exhibits "dynamic" interfacial properties (i.e., it could be described as "smart" or "adaptive"). Unlike the current generation of fiber reinforced composites, the strength does not need to be sacrificed to improve the toughness. 
(3) It is possible to design a composite with a single crystal oxide fiber and an oxide matrix of the same chemical composition, such that the transformation weakener is adjacent to that composition on the equilibrium phase diagram. Then one could minimize the thermal expansion mismatch, and eliminate the high temperature chemical reaction (I.e., the $(\Delta \alpha) \Delta \mathrm{G}_{\text {chem }}$ problem).

The energy dissipative mechanisms are many fold:

(i) They involve using crack energy to nucleate the phase transformation.

(ii) This may also cause autocatalytic nucleation of transformation along the interface promoting long fiber pullout or interfacial debonding.

(iii) There is an increased surface energy contribution with interfacial microcracking or shearing accompanying the transformation.

(iv) Increased frictional work needs to be done by the crack to achieve interfacial debonding, so that there is a need to optimize coating thickness to achieve an optimum process zone.

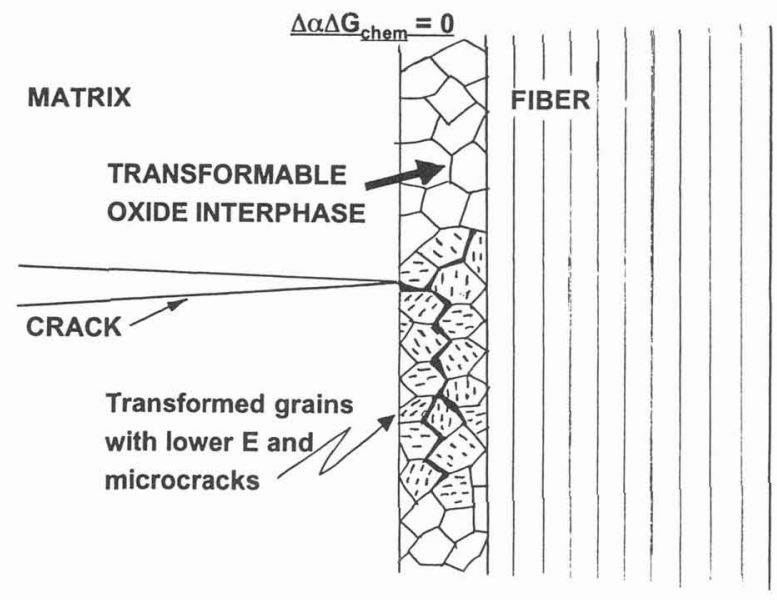

Figure 3: Transformation Weakening of Composite Interfaces
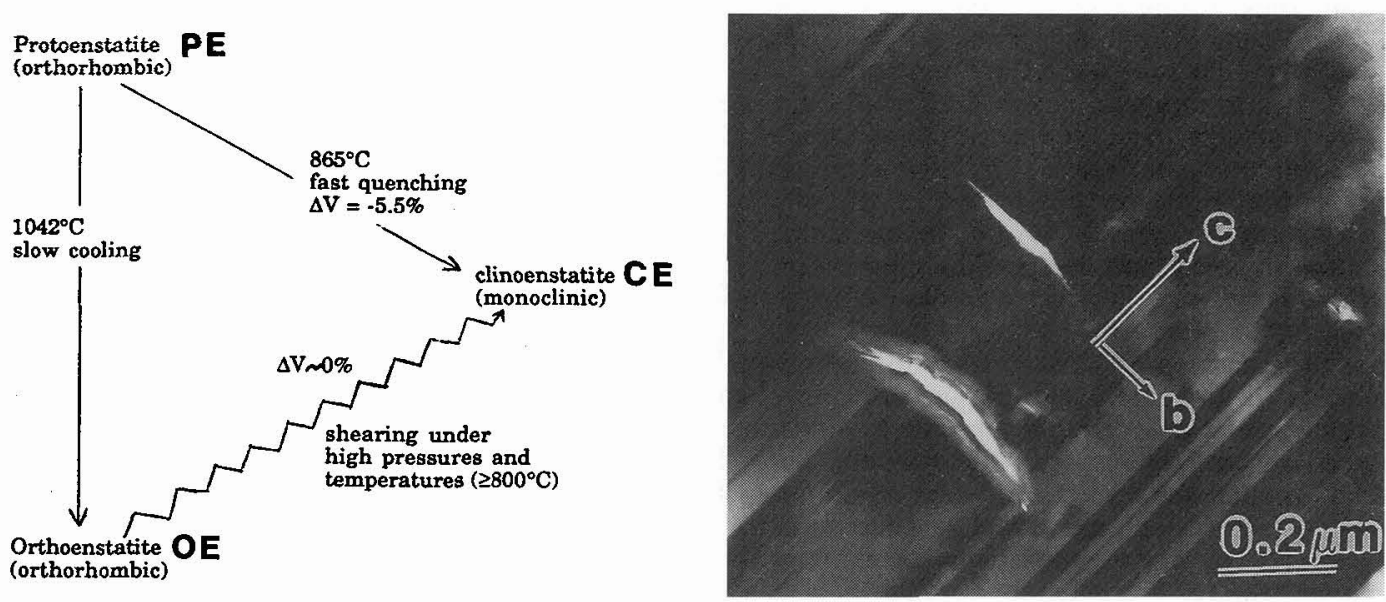

Figure 4: Polymorphs of enstatite $\left(\mathrm{MgSiO}_{3}\right)$

Figure 5: TEM micrograph of intergranular microcracks in CE

\subsubsection{Example of a Transformation Weakener - Enstatite $\left(\mathrm{MgSiO}_{3}\right)$}

Enstatite, magnesium metasilicate $\left(\mathrm{MgO} \cdot \mathrm{SiO}_{3}\right)$ is a pyroxene chain silicate and a major component of steatite insulating ceramics. The relationship between the polymorphs is illustrated in Fig. 4 [7]. In a recent review, Kriven [7] pointed out that transformation toughening in $\mathrm{ZrO}_{2}$ was preceded by 
"transformation weakening" in enstatite, since the deleterious properties of these ceramics were attributed to the uncontrolled, spontaneous transformation of articles in which the enstatite grains exceeded a critical grain size of $\sim 7 \mu \mathrm{m}$. The othorhombic (PE) to monoclinic (CE) transformation is accompanied by a unit cell volume decrease of $5.5 \%$, as well as a unit cell shape change of $18.3^{\circ}$.

The components of the unconstrained transformation strain tensor with respect to the orthorhombic lattice are calculated to be:

$$
\begin{aligned}
& \mathrm{e}_{11^{\mathrm{t}}}=\left(\mathrm{a}_{\mathrm{CE}} / \mathrm{aPE}_{\mathrm{PE}}\right) \cos (90-\beta)=-0.014 \\
& \mathrm{e}_{22^{\mathrm{t}}}=\left(\mathrm{b}_{C E} / \mathrm{b}_{P E}\right)-1=0.009 \\
& \mathrm{e}_{33^{\mathrm{t}}}=\left(\mathrm{c}_{C E} / \mathrm{c}_{P E}\right)-1=-0.028 \\
& \mathrm{e}_{13^{\mathrm{t}}}=\mathrm{e}_{32^{\mathrm{t}}}=(1 / 2) \tan (90-\beta)=-0.165
\end{aligned}
$$

Thus it is seen that there is furthermore a significant anisotropy and contraction in the [c] $]_{C E}$ direction of product phase. This is the explanation for intragranular microcracks in the overaged CE grains seen in SEM. Closer examination by TEM confirmed that the microcracks were indeed aligned perpendicular to the $[\mathrm{c}]_{\mathrm{CE}}$ direction (Figure 5).

\subsubsection{Preliminary Studies on Model Cylinder System}

Preliminary model experiments have been carried out by the Kriven group on a system of enstatite $\left(\mathrm{MgSiO}_{3}\right)$ as a transformation weakened coating around a machined, dense cylinder of titania $\left(\mathrm{TiO}_{2}\right)$ with which it was chemically compatible on their phase diagram, so that no intermediate phases form between them. The results will be fully presented elsewhere [79]. The coatings were chemically deposited by dipping into a charged colloidal suspension. The as-HIPped enstatite had a fine grain size $(<$ $1 \mu \mathrm{m}$ ) which did not permit spontaneous, thermally-induced transformation, as confirmed by TEM and $\mathrm{SAD}$ diffraction patterns. On prolonged annealing at $1350^{\circ} \mathrm{C}$ for 100 hours however, grain growth and spontaneous transformation to the CE phase occurred on cooling to room temperature. TEM examination revealed that the enstatite grains were transformed and microcracked. When the as-HIPped cylinder system underwent the push-out test, the untransformed coating led to brittle fracture of the specimen at a shear stress of $105 \mathrm{MPa}$, without any evidence of debonding at the interphase. On the other hand, the annealed, thermally transformed coating did permit the cylinder to be pushed out at a significantly lower shear stress of $45 \mathrm{MPa}$.

\subsubsection{Preliminary Studies on Composites}

Bulk mechanical data was obtained from fibrous composites broken in three point flexure. The composites were fabricated by a co-extrusion method to produce multi-filament arrangements of fibrous titania regions surrounded by a coating of enstatite and further surrounded by more polycrystalline $\mathrm{TiO}_{2}$. A honeycomb microstructure was obtained (Figure 9). Composites sufficient for several bend bars were hot pressed and machined, polished annealed for various hold times and tested in flexure. Once again the unannealed specimens fractured in a typical brittle mode, while with increasing grain growth, the bars were visibly bent but still in one piece at the end of the test. This was suggestive of ductile composite behavior, as confirmed by flexure stress $v s$ deflection data. It was seen that while un-annealed specimens broke in a typical elastic mode, the transformation weakened specimens showed a significant work of fracture (WOF) or area under the curve. An encouraging figure of a $1000 \mathrm{~J} / \mathrm{m}^{2}$ for the WOF associated with transformation weakened interfaces was obtained. In SEM micrographs of the fracture surfaces of as hot pressed samples in the normal SE + BSE mode as well as in the back scattered mode, where atomic number contrast readily permitted the distinction between the $\mathrm{TiO}_{2}$ "matrix" and the enstatite coating regions. The fracture surface was common to both phases, and obviously not preferable to either. In annealed specimens, however, pullout of the fibrous regions was strikingly evident, as well as significant fracture along the transformation weakened interfacial regions. Suggestions of bridging by the polycrystalline $\mathrm{TiO}_{2}$ regions were also apparent.

\subsection{Mechanical rearrangement of ferroelastic domains}

A "ferroelastic" transformation is considered to be one in which there is a group-subgroup relationship between a protypic parent and symmetry-equivalent, product crystal structures [80]. The symmetry equivalent options of the parent phase give rise to different "domains" or contiguous regions of a crystal which have the same orientation. In high symmetry crystals, these domains may be twin related. Under an external stress, the crystal may reorient itself by domain wall movement so as to minimize its free energy [81]. Vickers indentation of mechanically aligned domains in tetragonal zirconia has clearly demonstrated 
that crack propagation may be notably hindered by such an energy dissipative toughening mechanism involving reorientation of domains [82]. A three-fold toughening increase has been observed at room temperature in zirconia which has a relatively small spontaneous strain $\left(\varepsilon_{\mathrm{s}}\right)$ of 0.0087 [83]. Significantly larger spontaneous strains have been calculated for some of the compounds listed in Table 1 . For example, $\varepsilon_{\mathrm{S}}=0.0914$ for the hexagonal (A) to monoclinic (B) transformation in dysprosia $\left(\mathrm{Dy}_{2} \mathrm{O}_{3}\right)$, which occurs at $\sim 2100^{\circ} \mathrm{C}$. This suggests that larger toughening effects up to significantly elevated temperatures may be achieved by ferroelastic domain rearangement in single phase monolithic ceramics. This research could be further pursued $[84,85]$.

\subsection{Large Force Actuators}

A relatively unexplored area is the application of non-perovskite, martensitic transformations in ceramics as actuators which could be thermally or mechanically triggered. They may be "one shot" applications e.g. at high temperatures, or in the case of epitaxially grown, aligned crystals, reversible transformations leading to multiple cycles. Since it is known that such transformation can be nucleated by a critical resolved force equal to 0.22 of the unconstrained transformational strain applied in the correct crystallographic direction $[86-89,69]$, it is anticipated that martensitic actuators could be coupled with a convential actuator (e. g. lead zirconate titanate or "PZT") to provide the nucleating stimulous.

\subsection{Conclusion}

A brief, incomplete survey of phase transformations in ceramics as been presented. To date only the tetragonal to monoclinic transformation in single phase zirconia $\left(\mathrm{ZrO}_{2}\right)$ and cubic to tetragonal transformation in lead titanate $\left(\mathrm{PbTiO}_{3}\right)$ have demonstrated martensitic mechanisms in agreement with crystallographic calculations. Displacive transformations have been reported in a variety of ceramic materials, but the data is very scanty and incomplete. Nevertheless, useful applications have been demonstrated by improving the toughness of structural ceramic composites. Transformations with significant volume increases operate as transformation tougheners, as seen in zirconia and terbia $\left(\mathrm{Tb}_{2} \mathrm{O}_{3}\right)$ On the other hand, ceramics with sufficient volume decreases on cooling, or large unit cell shape changes, are useful as "transformation weakeners" of strategic interfacial interphases in fiber-reinforced or laminated composites, thereby leading to overall toughening of the composites. Mechanical rearrangement of domains resulting from ferroelastic mechanisms in twinned tetragonal zirconia crystals have been shown to improve the toughness of single phase monolithic ceramics. Finally, reversible or irreversible displacive transformations in ceramics may also be used as large force actuators. Thus, ceramic phase transformations are a fruitful area of research with highly desirable technological applications.

\section{Acknowledgements}

This work was supported by the US Air Force Office of Scientific Research through Dr. Alexander Pechenik, under grant numbers F49620-93-1-0227 and F49620-1-0562. It is a pleasure for me to acknowledge valuable discussions with my graduate student, J. L. Shull, Jr.

\section{References}

[1] R. E. Newnham, Structure-Property Relations in Electronic Ceramics, (Springer-Verlag, New York, 1975).

[2] W. D. Kingery, H. K. Bowen and D. R. Uhlman, Introduction to Ceramics, (John Wiley and Sons, New York, 1976.

[3] R. C. Garvie, R. H. J. Hannink and R. T. Pascoe, Nature (London) 258 (1975) 703-704.

[4] S. W. Kennedy, W. M. Kriven and W. L. Fraser, "Structural Transformations in $\mathrm{KNO}_{3}, \mathrm{RbNO}_{3}$ and $\mathrm{NH}_{4} \mathrm{Br}$," Int. Conf. on Martensitic Transformations (ICOMAT), Cambridge Massachusetts, USA 1979, W.

S. Owen, Ed. Dept. Materials Science and Eng., MIT, Cambridge, Massachusetts, USA 1979) pp 208-213.

[5] W. M. Kriven, "Shear Transformations in Inorganic Materials," International Conference on Solid to Solid Phase Transformations, Pittsburgh, USA 1981, H. I. Aaronson, D. E. Laughlin, R. F. Sekerka and C. M. Wayman, Eds. (AIME Publ., New York, 1982), pp. 1507-1532.

[6] W. M. Kriven, "Displacive Transformation Mechanisms in Zirconia Ceramics and Other NonMetals," Tailoring Multiphase and Composite Ceramics, University Park, Pennsylvania, USA, 1985, R. E. Tressler, G. L. Messing, C. G. Pantano and R. E. Newnham, Eds. (Plenum Press, New York, 1986) pp 223237.

[7] W. M. Kriven, J. Am. Ceram. Soc. 71 [12] (1988) 1021-1030. 
[8] W. M. Kriven, "Martensitic Toughening of Ceramics," Int. Workshop on First Order Displacive Phase Transformations, Oakland, California, USA, 1988. Publ in Mat. Sci. and Eng. A127 (1990) 249-255. [9] W. M. Kriven, "Phase Transformations in Ceramics," 51st Ann. Meeting of the Microscopy Society of America, Cincinatti, Ohio, USA 1993, G. W. Bailey and C. L. Rieder, Eds. (San Francisco Press, San Francisco, California, USA, 1993) pp 952-953.

[10] Y. J. Kim, I. Nettleship and W. M. Kriven, J. Am. Ceram. Soc., 75 [9] (1992) 2407-2419.

[11] Z. Mursic, T. Vogt and F. Frey, Acta Cryst. B48 (1992).

[12] C. Ibarra-Ramirez, M. E. Villafuerte-Castrejon, A. R. West, J. Mater. Sci. 20 (1985) 812-816.

[13] J. Angenault, J. C. Couturier, J. P. Souron, D. Silii and M. Quarton, J. Mater. Sci. Lett. 11 (1992) $1705-1707$.

[14] C. C. Chou and C. M. Wayman, Metall. Transactions. JIM 33 (1992) [3] 306-317.

[15] C. Z. Zha, A. G. Kalinichev, J. D. Bass, C.T.A. Suchicital and D. A. Payne, J. Appl. Phys. 72 [8] (1992) 3705-3707.

[16] P. Yang and D. A. Payne, "Shape Memory and Superelasticity for Ceramics with Field-induced Antiferroelectric-Ferroelectric Phase Transformations," Int. Conf. on Martensitic Transformations '92 (ICOMAT 92); Monterey, California, USA; July 1992; C. M. Wayman and J. Perkins, Eds. (Monterey Insitiute of Advanced Studies, P. O. Box 4427, Carmel, CA 93921, USA, 1993) pp 719-724 .

[17] C. C. Chou, K. Wakasa and C. M. Wayman, "Crystallography of the Cubic to Tetragonal Transformation in Lead Titanate Single Crystals," Int. Conf. on Martensitic Transformations '92 (ICOMAT 92); Monterey, California, USA; July 1992; C. M. Wayman and J. Perkins, Eds. (Monterey Insitiute of Advanced Studies, P. O. Box 4427, Carmel, CA 93921, USA, 1993) pp 695-700 .

[18] L. C. Yang and C. M. Wayman, Mat. Sci and Eng., in press.

[19] L. C. Yang and C. M. Wayman, Mat. Sci. and Eng., in press.

[20] J. Li, C. M. Huang, G. Xu and C. M. Wayman, Mat. Lett. 21 (1994) 105-110.

[21] J. Li and C. M. Wayman, Acta Metall. et Mater. 43 [10] (1995) in press.

[22] J. Li and C. M. Wayman, Mat. Lett., in press.

[23] J. Li and C. M. Wayman, J. Am. Ceram. Soc., in press.

[24] J. Li and C. M. Wayman, Phys. Rev. B, in press.

[25] C. C. Chou, J. Li and C. M. Wayman, Mat. Res. Symp. Proc., Vol. 238 (1992).

[26] B. Himmel, Th. Gerber, W. Heyer and W. Blau, J. Mater. Sci. 22, (1987) 1374-137.

[27] R. L. Withers, J. G. Thompson and T. R. Welberry, Phys. Chem. Minerals 16, (1989) 517-523.

[28] K. Byrappa, J. Mater. Sci. Lett. 8, (1989) 703706.

[29] R. E. Newnham and H. D. Megaw, Acta Crystallogr., 13 (1960) 303-312.

[30] G. Chiari, G. Gazzoni, J. R. Craig, G. V. Gibbs, and S. J. Louisnathan, Am. Mineral. 70 [9-10] (1985) 969-974.

[31] C. E. Semler and W. R. Foster, J. Am. Ceram. Soc. 52 [12] (1969) 679-680.

[32] C. E. Semler and W. R. Foster, J. Am. Ceram. Soc. 53 [10] (1970) 549-551.

[33] B. Yoshiki and K. Matsumoto, J. Am. Ceram. Soc. 34 [9] (1951) 283-286.

[34] W. F. Müller, "On the Polymorphism of $\mathrm{BaAl}_{2} \mathrm{Si}_{2} \mathrm{O}_{8}$," Electron Microscopy in Mineralogy, Berkeley, California, USA 1975, H. R. Wenk, Ed. (Springer-Verlag, New York, 1976), pp. 354-360.

[35] G. Oehlschlegel, K. Abraham, O. W. Flörke, Kristall und Technik, 11 [1] (1976) 59-72.

[36] I. Lee and J. Covino, Mat. Res. Bulletin 29 [1] (1994) 55-62.

[37] J C. Debsikdar and O. S. Sowemimo, J.Mater. Sci. 27 (1992) 5320-5324.

[38] Y. Takéuchi and G. Donnay, Acta Crystallogr. 12 (1959) 465-470.

[39] N. P. Bansal and C. H. Drummond, III, J. Am. Ceram. Soc. 76 [5] (1993) 1321-1324.

[40] R. A. Lange, I. S. E. Carmichael, and J. F. Stebbins Amer. Mineral. 71 (1986) 938-945.

[41] D. C. Palmer, E. K. H. Salje, and W. Schmahl Phys. Chem. Minerals 16 (1989)714-719.

[42] I.W.M. Brown, C. M. Cardile, K. J. D. MacKenzie, M. J. Ryan, and R. H. Meinhold, Phys. Chem. Minerals 15 (1987) 78-83.

[43] B. L. Phillips, R. J. Kirkpatrick, and A. Putnis, Phys. Chem. Minerals 16 (1988) 591-598.

[44] D. Taylor and C.M.B. Henderson, Am. Mineral. 53 [9-10] (1968) 1476-1489.

[45] J. F. Schairer and N. L. Bowen, Amer. J. Sci. 253 [12] (1955) 681-746.

[46] I. Warshaw and Rustum Roy, Inor. Chem. 1 [3] (1962) 719-720.

[47] B. Cockayne, J. Less-Common Metals 114 (1985) 199-206.

[48] T. Noguchi and M. Mizuno, Yogyo Kogaku Zasshi 70 [6] (1967) 834-839.

[49] J. S. Abell, I. R. Harris, B. Cockayne, and B. Lent, J. Mater. Sci. 9 (1974) 527-537.

[50] A. Ya. Neiman, E. V. Tkachenko, L. A. Kvichko, and L. A. Kotok, Russian J. Inorg. Chem. 25 [9] (1980) 1294-1297.

[51] C. D. Brandle and H. Steinfink, Inorg. Chem. 8 [6] (1969) 1320-1324.

[52] A. N. Christensen and R. G. Hazell, Acta Chemica Scandinavica 45 (1991) 226-230.

[53] H. Yamane, M. Omori, A. Okubo, and T. Hirai, J. Amer. Ceram. Soc. 76 [9] (1993) 2382-2384.

[54] P. D. Jero and W. M. Kriven, J. Amer. Ceram. Soc. 71 [11] (1988) C454-C455. 
[55] E. H. Nickel, J. F. Rowland, J. A. Maxwell, Canadian Mineral. 6 (1958) 264-272.

[56] M. Mellini, Tschermaks Mineralogische und Petrographische Mitteilungen 28 (1981) 99-112.

[57] V. I. Simonov and N. V. Belov, Doklady Akademii Nauk SSSR 130 (1960) 167-170.

[58] M. A. Petrova, A. S. Novikova, and R. G. Grebenshchikov, Inor. Mater. 18 [2] (1982) 287-291.

[59] D. J. Green, R. H. J. Hannink and M. V. Swain, Transformation Toughening of Ceramics. (CRC Press, Boca Raton, Florida, USA, 1989).

[60] A. H. Heuer and L. W. Hobbs, Eds., Science and Technology of Zirconia I. (The American Ceramic Society, Columbus, Ohio, USA, 1981). Published as Adv. in Ceramics 3 (1981).

[61] N. Claussen, M. Rühle and A. H. Heuer, Eds., Science and Technology of Zirconia II. (The American Ceramic Society, Columbus, Ohio, USA 1984). Published as Adv. in Ceramics 12 (1984).

[62] Proc. of the 2nd US-Australian-West German Transformation Toughening Workshop, Lorne, Victoria, Australia, April 15-19 (1985), Part I. J. Am. Ceram. Soc. 69 [3] (1986) 169-298. Part II. J. Am. Ceram. Soc. 69 [3] (1986) 511-584.

[63] A. G. Evans and R. M. Cannon, Acta Metall. 34 [5] (1986) 761-800.

[64] S. Somiya, N. Yamamoto, H. Yanagida, Eds.Science and Technology of Zirconia III. (The American Ceramic Society, Westerville, Ohio, USA, 1986). Published as Adv. in Ceramics 24.

[65] A. H. Heuer, N. Claussen, W. M. Kriven, M. Rühle, J. Am. Ceram. Soc. 65 [12] (1982) 642-650.

[66] G. K. Bansal and A. H. Heuer, Acta Metall. 20 [11] 1281-89 (1972). Part II. 22 [4] (1974) 409-17.

[67] W. M. Kriven, W. L. Fraser and S. W. Kennedy, "The Martensite Crystallography of Tetragonal Zirconia," in Science and Technology of Zirconia I, A. H. Heuer and L. W. Hobbs, Eds. (The American Ceramic Society, Columbus, Ohio, USA, 1981). Published as Adv. in Ceramics 3 (1981) pp 82-97.

[68] M. A. Choudrey and A. G. Crocker, "Theory of Twinning and Transformation Modes in Zirconia," Science and Technology of Zirconia II. N. Claussen, M. Rühle and A. H. Heuer, Eds. (The American Ceramic Society, Columbus, Ohio, USA 1984). Published as Adv. in Ceramics 12 (1984) pp46-53.

[69] W. M. Kriven, "Transformation Mechanism of Spherical Zirconia Particles in Alumina," Science and Technology of Zirconia II, N. Claussen, M. Rühle and A. H. Heuer, Eds. (The American Ceramic Society, Columbus, Ohio, USA, 1984). Published as Advances in Ceramics, 12 (1984) pp. 64-77.

[70] R. M. McMeeking and A. G. Evans, J. Am. Ceram. Soc. 65 [5] (1982) 242-246.

[71] A. G. Evans, "Toughening Mechanisms in Zirconia Alloys," Science and Technology of Zirconia II, N. Claussen, M. Rühle and A. H. Heuer, Eds. (The American Ceramic Society, Columbus, Ohio, USA, 1984). Published as Advances in Ceramics, 12 (1984) pp. 193-212.

[72] A. G. Evans and R. M. Cannon, Acta Metall. 34 [5] (1986) 761-800.

[73] O. Sudre, M. S. Thesis, University of Illinois at Urbana-Champaign, Illinois, USA (1987).

[74] P. D. Jero, Ph. D. Thesis, University of Illinois at Urbana-Champaign, Illinois, USA (1988).

[75] P. D. Jero and W. M. Kriven, "High Temperature Transformation Toughening of Magnesia by Terbia," Science and Technology of Zirconia V, S. P. S. Badwal, M. J. Bannister and R. H. J. Hannink, Eds. (Technomic Publishing Comp., Lancaster, UK and Basel, Switzerland, 1993) pp 190-197.

[76] O. Sudre, K. R. Venkatachari and W. M. Kriven, "Kinetics and Crystallography of the Monoclinic (B) to Cubic (C) Transformation in Dysprosia $\left(\mathrm{Dy}_{2} \mathrm{O}_{3}\right)$," Science and Technology of Zirconia V, S. P. S. Badwal, M. J. Bannister and R. H. J. Hannink, Eds. (Technomic Publishing Comp., Lancaster, UK and Basel, Switzerland, 1993) pp 180-189.

[77] Y. J. Kim, Ph. D. Thesis, University of Illinois at Urbana-Champaign, Illinois, USA, (1991).

[78] Y. J. Kim and W. M. Kriven, Phil. Mag., submitted.

[79] W. M. Kriven, C. M. Huang, D. Zhu, Y. Xu, and S. C. Mirek, Ceram. Sci. and Eng. Proc. (1996), to be published.

[80] K. Aizu, J. Phys. Soc. of Japan 28 (1970) [3] 706-716.

[81] V. K. Wadhawan, Phase Transitions 3 (1981) 3-103.

[82] C. J. Chan, F. F. Lange, M. Ruhle, J. F. Jue and A. V. Virkar, J. Am. Ceram. Soc. 74 [4] (1991) 8$7-813$.

[83] A. V. Virkar, J. F. Jue, P. Smith, K. Mehta and K. Pettyman, Phase Transitions 35 (19910 27-46.

[84] W. M. Kriven, "Twinning in Structural Ceramics," Twinning in Advanced Materials, M. H. Yoo and M. Wuttig, Eds. (The Minerals, Metals and Materials Society (TMS), Warrendale , Pennsylvania, USA, 1994) pp 435-448.

[85] P. Müllner and W. M. Kriven, "On the Role of Deformation Twinning in Domain Reorganization and in Domain Reorientation in Ferroelastic Crystals," Philos. Mag., submitted.

[86] A. H. Heuer and M. Rühle, Acta Metall. 33 [12] (1985) 2101-2112.

[87] Prof. J. W. Christian, Oxford University, UK, private communication.

[88] M. Rühle and W. M. Kriven, Ber. Bunsegesellschaft fur Physik. Chem. 87, (1983) 222-228.

[89] M. Rühle and A. H. Heuer, "Phase Transformations in $\mathrm{ZrO}_{2}$-Containing Ceramics: II, The Martensitic Reaction in $\mathrm{t}-\mathrm{ZrO}_{2}$," Science and Technology of Zirconia II, N. Claussen, M. Rühle and A. H. Heuer, Eds. (The American Ceramic Society, Columbus, Ohio, USA, 1984). Published as Advances in Ceramics. 12 (1984) nn. 14-32. 